\title{
СВОБОДА ОЦЕНКИ ДОКАЗАТЕЛЬСТВ В УГОЛОВНОМ СУДОПРОИЗВОДСТВЕ: ПРАВОВЫЕ ОСНОВЫ, СОДЕРЖАНИЕ, ГАРАНТИИ
}

\begin{abstract}
Аннотация: В статье рассматривается содержание принципа свободы оценки доказательств в уголовном судопроизводстве, анализируются два его взаимосвязанных аспекта данного: запрет внешнего вмешательства в оценочную деятельность суда, прокурора, следователя, дознавателя и одновременное предоставление им внутренней свободы оченки доказательств. Анализируются требования, предъявляемые к свободной оценке доказательств, призванные исключить принятие произвольных, необоснованных решений, включая обязанность субъектов оиенки доказательств руководствоваться положениями об обязательном доказывании отдельных обстоятельств доказательствами определенного вида, о запрете на использование некоторых сведений в качестве доказательств, об освобождении от процессуальной деятельности по доказыванию общеизвестных фактов, преюдициально установленных фактов, правовых презумпций и обстоятельств, признанных сторонами, установление совести как нравственного ориентира при оценке доказательств, и др. Исследование основано на анализе отечественного уголовно-прочессуального законодательства, правовых позииий Конституичонного Суда РФ, Пленума Верховного Суда РФ и решений Верховного Суда РФ по конкретным уголовным делам. Автором формулируется вывод о том, что следствием свободной оченки доказательств является возможность постановления обвинительного приговора при отсутствии прямых доказательств. Формулируются предложения о дополнении УПК РФ статьей «Основания освобождения от доказывания» и включении в нее норм об освобождении от доказывания общеизвестных фактов, а также обстоятельств, признанных сторонами.
\end{abstract}

Ключевые слова: Свобода оиенки доказательств, принцип, уголовное судопроизводство, доказательство, внутреннее убеждение, независимость судей, полиграф, преюдииия, презумпии, общеизвестные факты.

Abstract: This article examines the content of the principle of freedom of assessment of evidence in criminal procedure; two of its interconnected aspects are being analyzed: prohibition of external interference into assessment work of the court, prosecutor, investigator, detective, and at the same time allowing them internal freedom of assessment of evidence. The author analyzes the guidelines for the evidence assessment, put in place to eliminate arbitrary and unfounded decisions, which include: the duty of the subjects of evidence assessment to adhere to the positions on mandatory proof of separate circumstances by specific types of evidence; prohibition of use of certain data as evidence; on relieving from procedural work with regards to proving facts of general knowledge, prejudicially established facts, legal presumptions and circumstances admitted by both parties; setting conscience as a moral compass during assessment of evidence, etc. The author formulates the conclusion that the consequence of freedom of evidence assessment is the possibility of a guilty verdict without presence of direct evidence.

Keywords: Freedom of evidence assessment, Principle, Criminal procedure, Evidence, Belief, Judiciary independence, Polygraph, Prejudice, Presumption, General knowledge.

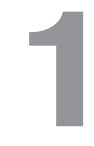

В статье 17 Уголовно-процессуального кодекса Российской Федерации (далее УПК) [1] впервые свобода оценки доказательств закреплена в качестве принципа уголовного судопроизводства: судья, присяжные заседатели, а также прокурор, следователь, дознаватель оценивают доказательства по своему внутреннему убеждению, основанному на совокупности имеющихся в уголовном деле доказательств, руководствуясь при этом законом и совестью (часть 1); никакие доказательства не имеют заранее установленной силы (часть 2).
Закрепленный в ст. 17 УПК принцип свободы оценки доказательств направлен на исключение какого бы то ни было внешнего воздействия на судью, присяжного заседателя, прокурора, следователя и дознавателя с целью понуждения их к принятию того или иного решения. Этим, в частности, обеспечивается действие провозглашенного в ч. 1 ст. 120 Конституции РФ [2] правила, согласно которому судьи независимы и подчиняются только Конституции Российской Федерации и федеральному закону [3].

Запрет на вмешательство в оценочную деятельность проявляется, например, в том, что суды 
апелляционной, кассационной, надзорной инстанций, отменяя приговор и направляя дело на новое судебное разбирательство либо при возвращении уголовного дела прокурору не могут предрешать вопросы, требующие оценки по внутреннему убеждению: о доказанности или недоказанности обвинения, о достоверности или недостоверности того или иного доказательства, преимуществах одних доказательств перед другими, о применении того или иного уголовного закона и о мере наказания (ч. 4 ст. 389.19 , ч. 7 ст. 401.16 , ч. 3 ст. 412.12 УПК). В случае, когда нижестоящий суд не согласен с указанием вышестоящего суда, когда, по его мнению, выполнение указания вышестоящего суда будет препятствовать постановлению законного, обоснованного и справедливого судебного решения, нижестоящий вправе, подчиняясь Конституции РФ (ч. 1 ст. 120) и федеральному закону, принять решение в пределах собственной компетенции [4].

Одной из гарантий принципа разумного срока уголовного судопроизводства после поступления уголовного дела в суд, если дело длительное время не рассматривается и судебный процесс затягивается, является право заинтересованных лиц обратиться к председателю суда с заявлением об ускорении рассмотрения дела. По результатам рассмотрения заявления председатель суда выносит мотивированное постановление, в котором при установлении оснований для ускорения рассмотрения дела может быть установлен срок проведения судебного заседания по делу и (или) могут быть приняты иные процессуальные действия для ускорения рассмотрения дела. При избрании председателем суда конкретных мер, необходимых для ускорения рассмотрения дела, следует учитывать недопустимость нарушения принципов независимости и беспристрастности судей. В связи с этим председатель суда не вправе, в частности, предрешать вопросы о достоверности или недостоверности того или иного доказательства, преимуществе одних доказательств перед другими, о том, какое решение должно быть принято судом при рассмотрении дела, а также совершать иные действия, направленные на вмешательство в деятельность судьи по осуществлению правосудия по конкретному делу (части 5 и 6 ст. 6.1 УПК; пункт 20 постановления Пленума Верховного Суда Российской Федерации и Пленума Высшего Арбитражного Суда Российской Федерации от 23 декабря 2010 года № 30/64 «О некоторых вопроcax, возникших при рассмотрении дел о присужде- нии компенсации за нарушение права на судопроизводство в разумный срок или права на исполнение судебного акта в разумный срок» [5]).

Во избежание оказания давления на присяжных заседателей закон устанавливает правило о том, что при произнесении напутственного слова председательствующему запрещается в какойлибо форме выражать свое мнение по вопросам, поставленным перед коллегией присяжных заседателей (ч. 2 ст. 340 УПК).

Вместе с тем, Верховный Суд РФ не признает указание присяжным заседателям на противоречия в доказательствах в напутственном слове председательствующего, нарушением уголовно-процессуального закона, влекущим отмену приговора по делу [6]. В литературе такой подход практики критикуется, поскольку «... суждения председательствующего о наличии противоречий между исследованными доказательствами... являются выводами... и оценочными суждениями» [7, с. 74], высказывать которые председательствующему запрещено п. 3 ч. 3 ст. 340 УПК РФ.

Гарантией против необоснованного вмешательства в оценочную деятельность следователя является положение ч. 3 ст. 39 УПК о том, что обжалование следователем указаний руководителя следственного органа приостанавливает их исполнение в случаях, когда указания касаются решений, принимаемых следователем по внутреннему убеждению: о привлечении лица в качестве обвиняемого, квалификации преступления, объеме обвинения, избрании меры пресечения, производстве следственных действий, которые допускаются только по судебному решению, о направлении дела в суд или его прекращении, об изъятии уголовного дела и передачи его другому следователю (ч. 3 ст. 39 УПК).

2. Принцип свободы оценки доказательств предоставляет судье, присяжному заседателю, прокурору, следователю и дознавателю также и внутреннюю свободу оценки доказательств, поскольку закон не устанавливает обязательной для участников уголовного судопроизводства силы (доказательственной значимости) тех или иных доказательств, не связывает оценку относимости, достоверности, достаточности доказательств какими-либо формальными предписаниями, не устанавливает минимального количества доказательств для признания тех или иных фактов доказанными.

В то же время принцип оценки доказательств закрепляет адресованное судье, присяжным за- 
DOI: $10.7256 / 1811-9018.2015 .7 .15745$

При цитировании этой статьи сноска на доі обязательна

\section{Право и политика 7 (187) 2015}

седателям, прокурору, следователю и дознавателю требование не только исходить при такой оценке из своего внутреннего убеждения и совести, но и основываться на совокупности имеющихся в уголовном деле доказательств и руководствоваться законом и совестью, что должно исключать принятие произвольных, необоснованных решений вопросов об относимости, допустимости, достоверности и достаточности доказательств [8].

Это положение подлежит применению в системной связи с иными законодательными нормами, устанавливающими порядок собирания, проверки и оценки доказательств в уголовном судопроизводстве, в частности статьями 74, 75, $81,87,88,234,235,240,302,305,307$ и др. УПК [9]. Указанные нормы, устанавливая порядок доказывания по уголовным делам, содержат правила оценки доказательств: в основу обвинительного приговора могут быть положены лишь доказательства, исследованные в судебном заседании и не вызывающие сомнения с точки зрения их достоверности и соответствия закону; обвинительный приговор не может быть основан на предположениях и постановляется лишь при условии, что в ходе судебного разбирательства виновность подсудимого в совершении преступления подтверждена совокупностью исследованных судом доказательств; при этом суд в приговоре должен указать доказательства, на которых основаны выводы суда в отношении подсудимого, и мотивы, по которым суд отверг другие доказательства; запрет использования в доказывании недопустимых доказательств; правило о толковании неустранимых сомнений в виновности лица в пользу обвиняемого; правило о том, что отказ подозреваемого, обвиняемого от дачи показаний или его молчание не имеют юридического значения и не могут быть истолкованы как свидетельство виновности указанного лица, а также что признание обвиняемым своей вины в совершении преступления может быть положено в основу обвинения лишь при подтверждении его виновности совокупностью имеющихся по уголовному делу доказательств; положение, согласно которому ни одно доказательство не имеет заранее установленной силы.

3. Требования, предъявляемые к свободной оценке доказательств.

Определения суда, постановления судьи, прокурора, следователя, дознавателя должны быть законными, обоснованными и мотивированными (ч. 4 ст. 7 УПК), а приговор суда должен быть законным, обоснованным и справедливым (ч. 1 ст. 297 УПК).

Чтобы исключить принятие произвольных, незаконных, необоснованных и несправедливых решений, закон предъявляет к свободной оценке доказательств судьей, присяжным заседателем, прокурором, следователем, дознавателем ряд требований.

3.1. Внутреннее убеждение указанных участников должно быть основано на совокупности имеющихся в деле доказательств.

Анализ доказательств, которые составляют основу внутреннего убеждения, должен содержаться в каждом решении по уголовному делу - в постановлении, определении, приговоре. Перечень доказательств, подтверждающих обвинение, является обязательным элементом обвинительного заключения, обвинительного акта, обвинительного постановления (п. 5 ч. 1 ст. 220, п. 6 ч. 1 ст. 225, ч. 1 ст. 226.7 УПК). При этом не только должна быть сделана ссылка на источники доказательств, но и приведено краткое содержание сведений, на основе которых суд, прокурор, следователь, дознаватель в порядке, определенном УПК, устанавливает наличие или отсутствие обстоятельств, подлежащих доказыванию при производстве по уголовному делу [10, п. 13].

Воскобитова Л.А. обоснованно подчеркивает, что «доказательства - необходимая объективная основа процессуального решения, также как и факты. Законодатель не для всех решений требует изложения доказательств. Но там, где это требуется, изложение доказательств должно быть таким, чтобы правоприменитель мог, ссылаясь на них, «отстраниться» и «спрятать» за ними собственное убеждение. Не судья так решил, а доказательства так велят решить дело» [11, с. 47].

Исключениями из этого правила являются: (1) постановление о привлечении в качестве обвиняемого; (2) вердикт присяжных заседателей; (3) приговор, постановленный в особом порядке принятия судебного решения при согласии обвиняемого с предъявленным ему обвинением (гл. 40 УПК); (4) приговор, постановленный в особом порядке судебного разбирательства уголовных дел при заключении досудебного соглашения о сотрудничестве (гл. 40.1 УПК); (5) приговор по делу, дознание по которому производилось в сокращенной форме (гл. 32.1 УПК). В указанных случаях на принимающем это решение лице не лежит обязанность привести его мотивы, и, следовательно, исключается проверка обоснованно- 
сти этих решений. Если же закон требует указания мотивов решения, то тем самым предполагается и возможность их последующей проверки [12].

Однако даже в тех случаях, когда закон не предусматривает обязанности приводить в решении доказательства, которые легли в основу внутреннего убеждения лица или органа, его принявшего, это не означает, что решение может приниматься произвольно.

Так, в постановлении о привлечении лица в качестве обвиняемого не приводятся доказательства, совокупность которых оценена следователем как достаточная, дающая основание для обвинения лица в совершении преступления (ч. 1 и 2 ст. 171 УПК). Однако это не означает, что такое постановление может выноситься необоснованно, без указания обстоятельств, послужившие основанием для предъявления ему обвинения [13]. Конституционный Суд РФ отметил, что ст. 171 УПК в единстве с другими положениями уголовно-процессуального закона, устанавливающими основания для привлечения лица в качестве обвиняемого и порядок предъявления обвинения, «не допускает возможности ни привлечения лица в качестве обвиняемого, если вменяемые ему деяния, предусмотренные уголовным законом, не подтверждены достаточными доказательствами, ни неразъяснения обвиняемому существа предъявленного ему обвинения и его прав, ... в том числе права знать, в чем он обвиняется, возражать против обвинения и знакомиться в установленных уголовно-процессуальным законом случаях и порядке с содержащимися в материалах уголовного дела доказательствами» [14]. Отсутствие в постановлении ссылки на доказательства означает не их отсутствие, а лишь то, что они не сообщаются стороне защиты до окончания предварительного расследования.

Вердикт присяжных заседателей также не может быть произвольным, несмотря на то, что в нем не приводятся мотивы принятого решения. Напротив, он должен основываться на совокупности исследованных в судебном следствии доказательств, о чем присяжными приносится присяга («клянусь ... принимать во внимание все рассмотренные в суде доказательства, как уличающие подсудимого, так и оправдывающие его ...»- ч. 1 ст. 332 УПК). Кроме того, в напутственном слове председательствующий напоминает присяжным об исследованных в суде доказательствах, как уличающих подсудимого, так и оправдывающих его, не выражая при этом своего отношения к этим доказательствам и не делая выводов из них (п. 3 ч. 3 ст. 340 УПК).

Примером нарушения данного правила может служить дело по обвинению А., рассмотренного судом с участием присяжных заседателей. Установлено, что присяжный заседатель А., избранная старшиной, «во время перерыва в судебном разбирательстве ходила к гадалке, которая ответила, что подсудимый не виноват, и старшина говорила, чтобы все голосовали за то, что подсудимый не убивал Г. и Л. (как видно из результатов голосования, голоса разделились: 6 - за, 6 - против)». Данные обстоятельства расценены судом кассационной инстанции как свидетельствующие о возможном воздействии на мнение присяжных заседателей сведений, поступивших со стороны, полученных вне судебного заседания, при ответах на поставленные вопросы [15]. В связи с нарушением положений ст. 333 УПК РФ приговор отменен, уголовное дело направлено на новое рассмотрение в тот же суд в ином составе судей со стадии судебного разбирательства.

Объективность вердикта присяжных заседателей обеспечивается также требованиями его ясности, полноты, непротиворечивости, запретом предположительных формулировок ответов [16, с. 122-141].

3.2. При оценке доказательств судья, присяжный заседатель, прокурор, следователь, дознаватель должен руководствоваться законом.

Современное доказательственное право устанавливает высокие требования к средствам и способам доказывания. Во многих случаях закон прямо предусматривает ограничения и условия использования в качестве доказательств тех или иных сведений об обстоятельствах, имеющих значение для дела. Эти нормы обусловлены стремлением законодателя (1) исключить наименее достоверные средства доказывания либо (2) направлены на обеспечение прав и свобод личности в уголовном судопроизводстве (ст. 2 Конституции РФ).

К таким правилам, ограничивающим свободу оценки доказательств, можно отнести следующие.

3.2.1. Для доказывания некоторых обстоятельств закон требует обязательное получение доказательства определенного вида. Например, для установления причины смерти, характера и степени вреда, причиненного здоровью, возраста подозреваемого, обвиняемого, потерпевшего, когда это имеет значение для уголовного дела, а документы, подтверждающие его возраст, отсутствуют или вызывают сомнение и т.д. обязательно назначение 
DOI: $10.7256 / 1811-9018.2015 .7 .15745$

При цитировании этой статьи сноска на доі обязательна

\section{Право и политика 7 (187) • 2015}

и производство экспертизы (ст. 196 УПК). Это означает, что для доказывания указанных обстоятельств могут использоваться различные предусмотренные законом средства доказывания, однако среди них в обязательном порядке должно быть заключение эксперта. По делам о преступлениях, связанных с наркотическими средствами, психотропными, сильнодействующими и ядовитыми веществами, для определения вида средств и веществ (наркотическое, психотропное или их аналоги, сильнодействующее или ядовитое), их размеров, названий и свойств, происхождения, способа изготовления, производства или переработки, а также для установления принадлежности растений к культурам, содержащим наркотические средства или психотропные вещества либо их прекурсоры, требуются специальные знания, поэтому, как разъяснил Пленум Верховного Суда РФ, суды должны располагать соответствующими заключениями экспертов или специалистов [17].

3.2.2. Закон устанавливает запрет на использование определенных сведений в качестве доказательств.

3.2.2.1. К недопустимым доказательствам относятся показания подозреваемого, обвиняемого, данные в ходе досудебного производства по уголовному делу в отсутствие защитника, включая случаи отказа от защитника, и не подтвержденные подозреваемым, обвиняемым в суде (п. 1 ч. 2 ст. 75 УПК). Это правило обеспечивает соблюдение ст. 51 Конституции РФ и правил ч. 2 ст. 46, п. 6 ч. 4 ст. 47 УПК, ограждает допрашиваемого от самооговора, признания вины в результате применения к нему физического или психического насилия.

Европейский суд по правам человека в ряде своих решений отметил, что «право не давать показания при допросе в ходе следствия и привилегия против самообвинения являются общепринятыми международными стандартами, лежащими в основе понятия справедливого судебного разбирательства... Предоставляя обвиняемому защиту от ненадлежащего принуждения со стороны властей, эти иммунитеты позволяют избежать ненадлежащего отправления правосудия и обеспечить достижение целей статьи 6 Европейской конвенции о защите прав человека и основных свобод» $[18,19]$.

Закон не ставит допустимость таких показаний подозреваемого, обвиняемого в зависимость от правомерности либо неправомерности участия защитника в следственном действии, при котором были получены показания, - обвиняемый во всех случаях может распорядиться данным доказательством;
3.2.2.2. К недопустимым доказательствам относятся также показания потерпевшего, свидетеля, основанные на догадке, предположении, слухе, а также показания свидетеля, который не может указать источник своей осведомленности (п. 2 ч. 2 ст. 75 УПК). Эта положение основано на том, что все показания должны быть доступны для проверки и оценки их достоверности. Если в основе показаний лежат догадки, предположения, слухи или если лицо, дающее показание, скрывает или не может назвать источник своей осведомленности, такая проверка становится невозможной. Так, были признаны недопустим доказательством показания свидетеля К., являющегося сотрудником регионального управления Федеральной службы РФ по контролю за оборотом наркотиков по Архангельской области и, который как видно из данных им показаний не мог указать конкретный источник своей осведомленности [20].

Если лицо, дающее показание, скрывает или не может назвать источник своей осведомленности, сторона, заинтересованная в проверке показаний, лишена возможности задавать вопросы, допросить в суде лицо, являвшееся «источником» сведений, которые сообщает суду свидетель. Это нарушает равенство сторон и право на состязательность судебного разбирательства, а тем самым и обеспечение справедливого судебного разбирательства (ст. 6 Европейской конвенции о защите прав человека и основных свобод).

Показания лица, которое не может указать источник своей осведомленности, признаются недопустимым доказательством, даже если мотивы, которыми руководствовалось лицо, скрывая источник своей осведомленности, являются уважительными. Например, свидетель под псевдонимом С. дал показания о том, что в начале 2009 года он узнал о причастности X. к нападению в 2007 году на потерпевшего П. Однако свидетель отказался сообщить источник полученной им информации, сославшись на опасение расшифровки данных о своей личности. При таких обстоятельствах, с учетом положений п. 2 ч. 2 ст.75 УПК РФ при отказе свидетеля сообщить источник своей осведомленности о совершении преступления Х., суд признал данные показания недопустимым доказательством, мотивировав свои выводы в приговоре [21].

3.2.2.3. Не могут использоваться в качестве доказательств показания лиц, которые не подлежат допросу. Не могут быть допрошены в качестве свиде- 
теля: судья - об обстоятельствах, которые стали ему известны в связи с участием в производстве по делу (п. 1 ч. 3 ст. 56 УПК РФ, п. 2 ч. 3 ст. 69 ГПК РФ, ч. 5 ст. 56 АПК, ч. 5 ст. 4 Кодекса судейской этики); адвокат, защитник подозреваемого, обвиняемого - об обстоятельствах, ставших ему известными в связи с обращением к нему за юридической помощью или в связи с ее оказанием; адвокат - об обстоятельствах, которые стали ему известны в связи с оказанием юридической помощи; священнослужитель - об обстоятельствах, ставших ему известными из исповеди (ч. 3 ст. 56 УПК); третейский судья - о сведениях, ставших ему известными в ходе третейского разбирательства (ч. 2 ст. 22 Федерального закона «О третейских судах в Российской Федерации» [22]), и др.

Кроме того, закон устанавливает право граждан в отдельных случаях не давать показания (свидетельский иммунитет). В соответствии со ст. 51 Конституции РФ никто не обязан свидетельствовать против себя самого, своего супруга и близких родственников, круг которых определяется федеральным законом. Законом установлены и иные случаи освобождения от обязанности давать свидетельские показания: правом не давать показаний в установленных пределах наделены члены Совета Федерации и Государственной Думы (об обстоятельствах, которые стали им известны в связи с осуществлением ими своих полномочий), Уполномоченный по правам человека и др.

Как отметил Конституционный Суд РФ, «освобождение лица от обязанности давать показания, могущие ухудшить положение его самого или его близких родственников либо привести к разглашению доверенной ему охраняемой законом тайны, т.е. наделение этого лица свидетельским иммунитетом, является одной из важнейших и необходимых предпосылок реального соблюдения прав и свобод человека и гражданина» [23].

3.2.2.4. Не могут использоваться в качестве доказательств показания следователя, дознавателя о содержании показаний, данных подозреваемым, обвиняемым в ходе следственных действий.

Если показания, данные подозреваемым, обвиняемым в ходе предварительного расследования, по каким-либо причинам признаны недопустимым доказательством (например, эти показания были даны в ходе досудебного производства по уголовному делу в отсутствие защитника и не подтверждены обвиняемым в суде), то нельзя пытаться восстановить их допросом следователя или дознавателя относительно содержания показаний обвиняемого в досудебном производстве. Подобная практика еще в XIX веке справедливо оценивалась как «обходной путь», «проведение запретного материала в зал суда контрабандой» [24]. Следователь, дознаватель, лицо, осуществлявшее оперативно-розыскную деятельность, могут допрашиваться в качестве свидетелей, например, об обстоятельствах производства следственных и иных процессуальных действий. Так, для оценки допустимости протокола обыска по месту жительства обвиняемого суд допросил в качестве свидетелей всех лиц, принимавших участие в производстве обыска - понятых, представителя ЖКХ, эксперта-криминалиста и следователя [25]. С учетом полученных показаний суд признал протокол обыска недопустимым доказательством.

Однако указанные должностные лица не могут быть допрошены о содержании показаний обвиняемого, подозреваемого с целью восстановления содержания этих показаний: закон, исходя из предписания ч. 2 ст. 50 Конституции РФ, исключает возможность любого, прямого или опосредованного, использования содержащихся в недопустимых доказательствах сведений.

Конституционный Суд РФ отметил, что «не допускается воспроизведение в ходе судебного разбирательства содержания показаний подозреваемого, обвиняемого, данных в ходе досудебного производства по уголовному делу в отсутствие защитника и не подтвержденных им в суде, путем допроса в качестве свидетеля дознавателя или следователя, производившего дознание или предварительное следствие» [26].

Равным образом нельзя допрашивать и лиц, осуществляющих оперативно-розыскную деятельность, о содержании сведений, ставших им известными от подозреваемых, обвиняемых как во время, так и вне следственных действий. Особое значение это приобрело после включения в УПК РФ 2001 г. норм о непосредственном участии в уголовном судопроизводстве сотрудников, осуществляющих оперативно-розыскную деятельность: следователь вправе привлечь к участию в следственном действии должностное лицо органа, осуществляющего оперативно-розыскную деятельность, о чем делается соответствующая отметка в протоколе (ч. 7 ст. 164 УПК); должностные лица органов, осуществляющих оперативно-розыскную деятельность, могут быть привлечены к работе следственной группы (ч. 2 ст. 163 УПК). Так, признаны недопустимыми 
DOI: $10.7256 / 1811-9018.2015 .7 .15745$

При цитировании этой статьи сноска на doi обязательна

\section{Право и политика 7 (187) 2015}

доказательствами показания оперативного работника уголовного розыска РОВД г. Ставрополя и заместителя начальника отдела криминалистики прокуратуры Ставропольского края, данные ими в судебном заседании в качестве свидетелей. Они показали, что в ходе бесед с задержанными М. и А. последние признались в совершенных нападениях на водителей и рассказали об обстоятельствах убийств потерпевших, однако процессуально их показания не оформлялись. Поскольку так называемые беседы с задержанными являлись не чем иным, как незаконным допросом, который производился в отсутствие адвокатов, без разъяснения задержанным положений ст. 51 Конституции РФ, эти показания в соответствии с ч. 2 ст. 50 Конституции РФ не должны были использоваться в суде в качестве доказательств [27].

3.2.2.5. Не имеют доказательственного значения сведения, полученные с использованием полиграфа.

В практике случаи использования полиграфа при производстве по уголовным делам не единичны. Известны попытки приобщения к материалам дела результатов опроса с использованием полиграфа, оформленных в виде справки (например, справкимеморандума о проведенных оперативно-розыскных мероприятиях и справки полиграфолога) либо рапорта (задания органу дознания на проведение исследований даются следователями в рамках отдельных поручений по выполнению оперативнорозыскных мероприятий); проведение «допроса с использованием технических средств»; приобщения к материалам дела заключения специалиста-полиграфолога; назначения так называемой судебной психофизиологической экспертизы (в отдельных случаях - комплексной психолого-психофизиологической экспертизы, проводимой полиграфологом и психологом).

Верховный Суд РФ в решениях последних лет придерживается последовательной позиции о том, что данные, полученные с помощью полиграфа, в соответствии с нормами УПК доказательствами не являются, исследованию в судебном заседании не подлежат [28-36].

Использование полиграфа в доказывании по уголовным делам недопустимо:

a) ввиду недостаточной разработки естественнонаучного (теоретического) обоснования психофизиологического метода и как следствие его несоответствие требованию научности [37] (в то время как в соответствии со ст. 8 Федерального закона «О государственной судебно-экспертной деятельности в Российской Федерации» [38] эксперт проводит исследования объективно, на строго научной и практической основе, в пределах соответствующей специальности, всесторонне и в полном объеме; заключение эксперта должно основываться на положениях, дающих возможность проверить обоснованность и достоверность сделанных выводов на базе общепринятых научных и практических данных). Без понимания природы процессов, происходящих в организме и психике человека при использовании полиграфа, невозможно установить научно обоснованные границы его применения;

б) поскольку использование полиграфа в доказывании по уголовным делам является вторжением в исключительную компетенцию суда, прокурора, следователя, дознавателя. Применение полиграфа направлено на оценку того, являются ли достоверными сообщаемые лицом сведения, в то время как оценка достоверности сведений об обстоятельствах, имеющих значение для дела, наряду с их допустимостью, относимостью и достаточностью законом возложена исключительно на суд, прокурора, следователя и дознавателя - лиц, осуществляющих уголовное судопроизводство, и наделенных на разных стадиях полномочиями по принятию решений (ч. 1 ст. 17 УПК) $[39,40]$.

3.2.3. По общему правилу, фактические обстоятельства, имеющие юридическое значение для правильного разрешения дела, должны пройти установленную законом процедуру доказывания, в том числе оценку доказательств. Однако существуют фактические обстоятельства, которые не требуют процессуальной деятельности по доказыванию. Это общеизвестные факты, преюдициально установленные факты, правовые презумпции и обстоятельства, признанные сторонами.

3.2.3.1. Общеизвестные факты - факты, которые должны быть известны в данной местности каждому разумному, взрослому, образованному, внимательному, обладающему житейским опытом человеку, в том числе участникам уголовного судопроизводства.

Общеизвестные факты не требуют доказывания, потому что истинность их очевидна, а доказывание является излишним.

К общеизвестным фактам можно отнести природные явления и стихийные бедствия (например, извержение исландского вулкана Эйяфьятлайокудль в апреле 2010 г., что привело к закрытию воздушного пространства над многими европейскими территориями), катастрофы (например, крушение польского 
президентского авиалайнера ТУ-154 под Смоленском 10 апреля 2010 г.), факты отечественной и всемирной истории (даты начала и окончания Олимпиад, первого полета человека в космос и т.д.), географические факты (расположение какой-либо местности), свойства и признаки вещей и материалов, сведения о том, каким днем недели было то либо иное число прошедшего месяца, на какие числа приходился в прошлом году государственный праздник, сведения о температуре воздуха или воды, время восхода и захода Солнца в тот или иной день в данной местности, и др.

В судебной практике последних лет общеизвестными и не нуждающимися в доказывании признавались самые разные факты: инфляция; фамилия Президента Российской Федерации [41]; наличие у судебных органов официальных сайтов; наличие у водителей такси денежных сумм [42]; причинение морального вреда в результате телесных повреждений [43], вследствие незаконного уголовного преследования $[45,45]$ и незаконного содержания под стражей [46, 47]; сниженные компенсаторные возможности по восстановлению здоровья граждан престарелого возраста [48]; факт того, что в январе 2000 года один из районов г. Грозного находился под полным контролем федеральных сил, и только федеральные военнослужащие имели возможность передвигаться по городу на бронетранспортерах и проверять удостоверения личности $[49,50]$, и др.

Положение о том, что обстоятельства, признанные судом общеизвестными, не нуждаются в доказывании, закреплено в ч. 1 ст. 61 Гражданского процессуального кодекса Российской Федерации (далее - ГПК) [51], ч. 1 ст. 69 Арбитражного процессуального кодекса Российской Федерации (далее - АПК) [52]. Однако в уголовно-процессуальном кодексе вопрос об общеизвестных обстоятельствах не регулируется. Поэтому представляется необходимым дополнить ст. 90 УПК РФ частью первой следующего содержания: «Обстоятельства, признанные судом, прокурором, следователем, дознавателем общеизвестными, не нуждаются в доказывании». Часть первую считать частью второй. Название статьи 89 изменить на «Основания освобождения от доказывания».

3.2.3.2. Преюдициально установленные факты (ст. 90 УПК).

В соответствии со ст. 90 УПК обстоятельства, установленные вступившим в законную силу приговором либо иным вступившим в законную силу решением суда, принятым в рамках гражданского, арбитражного или административного судопроизводства, признаются судом, прокурором, следователем, дознавателем без дополнительной проверки. При этом такие приговор или решение не могут предрешать виновность лиц, не участвовавших ранее в рассматриваемом уголовном деле.

Конституционный Суд РФ отметил, что «правило о преюдиции в уголовном судопроизводстве относится лишь к случаям, когда в ходе производства по уголовному делу подлежат установлению и исследованию те же фактические обстоятельства, которые уже были установлены решением, ранее принятым по другому делу» [53]. При этом ст. 90 УПК допускает преюдицию только при условии, что установленные ранее вынесенным судебным решением обстоятельства не вызывают у суда, прокурора, следователя, дознавателя сомнений, и, следовательно, не налагает на них обязанности признавать без дополнительной проверки те или иные обстоятельства, установленные вступившим в законную силу судебным решением.

Преюдициальным значением обладают не любые процессуальные решения, а лишь указанные в ст. 90 УПК. Так, постановление суда о законности произведенного обыска, вынесенное в соответствии с ч. 5 ст. 165 УПК, не имеет преюдициальной силы, а потому обстоятельства, установленные таким решением, не могут признаваться судом, прокурором, следователем, дознавателем без дополнительной проверки и препятствовать проверке допустимости полученных в ходе обыска доказательств и привлечению виновных в незаконном проникновении в жилище к предусмотренной законом ответственности [54].

3.2.3.3. Правовые презумпиии также не требуют доказывания. Примерами правовых презумпций в уголовном судопроизводстве являются презумпция невиновности (ст. 14 УПК), презумпция причинения вреда вследствие нарушения права на судопроизводство в разумный срок [5, п. 47]. Следует иметь в виду, что некоторые презумпции, например, презумпция невиновности, являются опровержимыми.

3.2.3.4. Обстоятельства, признанные сторонами.

УПК, в отличие от АПК, не содержит специальной статьи, посвященной освобождению от доказывания обстоятельств, признанных сторонами (ст. 70 АПК). Однако и в УПК имеется норма, вытекающая из состязательного характера уголовного судопроизводства, направленная на признание судом оценки обстоятельств, данной сторонами, 
DOI: $10.7256 / 1811-9018.2015 .7 .15745$

При цитировании этой статьи сноска на доі обязательна

\section{Право и политика 7 (187) $\bullet 2015$}

без дополнительной проверки: при рассмотрении в предварительном слушании ходатайства одной стороны об исключении доказательства, судья выясняет у другой стороны, имеются ли у нее возражения против данного ходатайства; при отсутствии возражений судья удовлетворяет ходатайство и выносит постановление о назначении судебного заседания, если отсутствуют иные основания для проведения предварительного слушания (ч. 5 ст. 234 УПК).

Схожее положение складывается и при особом порядке судебного разбирательства при согласии обвиняемого с обвинением (гл. 40 УПК). Воскобитова Л.А. справедливо отмечает, что при применении данного института объекты познания, предлагаемые обвинением и защитой, совпадают, что позволяет сокращать процедуру судебного познания [55, с. 102]. Однако в отличие от положения ч. 5 ст. 234 УПК обвинительный приговор в особом порядке может быть постановлен лишь если судья придет к выводу, что обвинение, с которым согласился подсудимый, обоснованно, подтверждается доказательствами, собранными по уголовному делу (ч. 7 ст. 316 УПК), то есть признание обстоятельств сторонами само по себе недостаточно для постановления судом приговора.

3.3. Оценивая доказательства, судья, присяжный заседатель, прокурор, следователь, дознаватель обязан руководствоваться своей совестью - нравственным ориентиром, необходимым для разрешения уголовного дела.

Обязанность профессиональных участников уголовного судопроизводства руководствоваться при оценке доказательств нравственными нормами закреплена помимо ч. 1 ст. 17 УПК в этических правилах, разработанными профессиональными сообществами: в Кодексе судейской этики [56]; Кодексе этики прокурорского работника [57]; Кодексе этики и служебного поведения федеральных государственных служащих Следственного комитета Российской Федерации [58]; Кодексе профессиональной этики сотрудника органа внутренних дел Российской Федерации [59]. На необходимость соблюдения нравственных норм при производстве по уголовному делу обращается внимание и в международных актах: в Кодексе поведения должностных лиц по поддержанию правопорядка [60. С. 319 - 325], Международном кодексе поведения государственных должностных лиц [61], Модельном кодексе поведения для государственных служащих [62].

Присяжные заседатели, участвующие в отправлении правосудия на непрофессиональной основе, приступая к исполнению своих обязанностей, торжественно клянутся разрешать уголовное дело по своему внутреннему убеждению и совести, не оправдывая виновного и не осуждая невиновного, как подобает свободному гражданину и справедливому человеку (ч. 1 ст. 332 УПК). В напутственном слове председательствующий напоминает присяжным содержание данной ими присяги (ч. 4 ст. 340 УПК).

4. В соответствии с ч. 2 ст. 17 УПК ни одно доказательство не имеет заранее установленной сильл.

Данное положение является противоположностью формальной системы (теории) оценки доказательств, существовавшей в российском уголовном судопроизводстве до 1864 года, в соответствии с которой закон заранее определял силу (вес, значение) каждого доказательства и количество доказательств, необходимых для разрешения дела. Задача суда и органов расследования заключалась лишь в подсчете процента достоверности, установленного для каждого доказательства, и вынесению на этой основе решения.

Действующая в настоящее время свободная оценка доказательств предполагает, что ни одно доказательство не имеет заранее установленной силы. Не имеют преимуществ перед другими доказательствами ни показания обвиняемого, ни заключение эксперта, ни вещественные доказательства и т.д. Каждое доказательство независимо от его вида подлежит оценке с точки зрения относимости, допустимости, достоверности, а все собранные доказательства в совокупности - достаточности для разрешения уголовного дела (ч. 1 ст. 88 УПК).

В процессуальной литературе в разное время высказывались суждения о преимущественном значении тех или иных доказательств. Так, Владимиров Л.Е. указывал, что «эксперты, основывающие свои заключения на какой-либо науке, суть научные судьи, приговор которых является решением специального вопроса в деле... Судьи и присяжные не могут быть посвящены в тайны науки в течение одного судебного заседания; они не могут критически относиться к экспертизе, для понимания оснований которой требуется целый ряд лет научных занятий. Им остается только следовать авторитетному указанию эксперта. Суд самостоятелен в выборе экспертов. Но раз последние выбраны, судья следует за ними, как слепой за своим поводырем» [63. С. 236].

Вороновский Н.Е. отмечал, что «свидетельское показание не является таким прочным фундаментом, на котором можно было бы построить расследование, а вещественное доказательство является 
лучшим по сравнению со свидетельскими показаниями доказательством» [64]. Выраженная в этих высказываниях мысль о преимуществе тех или иных доказательств перед другими до их проверки и оценки сегодня не применима.

Суды в своих решениях правильно указывают, что «в силу ч. 2 ст. 17 УПК РФ никакие доказательства не имеют заранее установленной силы, а, следовательно, равны между собой, вне зависимости от того, кем из правомочных лиц они представлены» [65], из положений ч. 2 ст. 17 УПК РФ следует, что все законные доказательства имеют одинаковую юридическую силу» [66].

Из правила о том, что ни одно доказательство не имеет заранее установленной силы, следует вывод о том, что обвинительный приговор может быть постановлен и при отсутствии прямых доказательств, на основе совокупности лишь косвенных доказательств. Примером применения данного положения может служить следующий вывод суда: «доводы осужденного о том, что в приговоре суда не приведены прямые доказательства его виновности в совершении преступлений, не влияют на законность и обоснованность приговора, так как в соответствии с законом никакие доказательства не имеют заранее установленной силы, на что ссылается и сам осужденный в кассационной жалобе, неправильно истолковывая указанное положение ст. 17 УПК РФ, как не имеют они преимуществ по содержанию, источнику, связи содержания с главными или побочными фактами, так и по другим обстоятельствам» [67].

5. Гарантии соблюдения принциипа свободы оценки доказательств.

Устранение нарушений, связанных с несоблюдением принципа свободной оценки доказательств, обеспечивается закрепленным в законе порядком обжалования и проверки, в том числе судебной, законности и обоснованности действий (бездействия) и решений дознавателя, следователя, прокурора и суда.

Нарушение требований ст. 17 УПК может повлечь отмену приговора. Так, был отменен приговор по делу о причинении вреда здоровью и убийстве, уголовное дело направлено на новое рассмотрение со стадии судебного разбирательства в тот же суд в ином составе судей, поскольку суд нарушил требования ст. 17 УПК РФ, по смыслу которой доказательства подлежат оценке в их совокупности [68].

\section{Библиография:}

1. Уголовно-процессуальный кодекс Российской Федерации от 18 декабря 2001 года № 174-Ф3 (ред. от 28 декабря 2013 года) // СПС КонсультантПлюс.

2. Конституция Российской Федерации. Принята всенародным голосованием 12 декабря 1993 года (с изм., внесенными Законами Российской Федерации о поправках к Конституции РФ от 30 декабря 2008 года № 6-ФКЗ, от 30 декабря 2008 года № 7-ФКЗ и от 5 февраля 2014 года № 2-ФКЗ) // СПС КонсультантПлюс.

3. Определение Конституционного Суда Российской Федерации от 24 ноября 2005 года № 504-О об отказе в принятии к рассмотрению жалобы гражданина Хисамиева Айрата Ирековича на нарушение его конституционных прав статьей 90 Уголовно-процессуального кодекса Российской Федерации // СПС КонсультантПлюс.

4. Определение Конституционного Суда Российской Федерации от 5 ноября 2004 года № 380-О по запросу Всеволожского городского суда Ленинградской области о проверке конституционности части шестой статьи 388 и части первой статьи 402 Уголовно-процессуального кодекса Российской Федерации // С3 РФ. 2005. № 3. Ст. 232.

5. Постановление Пленума Верховного Суда Российской Федерации и Пленума Высшего Арбитражного Суда Российской Федерации от 23 декабря 2010 года № 30/64 «О некоторых вопросах, возникших при рассмотрении дел о присуждении компенсации за нарушение права на судопроизводство в разумный срок или права на исполнение судебного акта в разумный срок» // БВС РФ. 2011. № 3.

6. Определение Судебной коллегии по уголовным делам Верховного Суда Российской Федерации от 30 июня 2004 года № 12-о04-14сп // СПС КонсультантПлюс.

7. Насонов С. А. Напутственное слово председательствующего в суде присяжных. М.: Р. Валент, 2006.304 с.

8. Определение Конституционного Суда Российской Федерации от 12 июля 2005 года № 323-О об отказе в принятии к рассмотрению жалобы гражданина Шейченко Владислава Игоревича на нарушение его конституционных прав статьями 17, 88, 234 и 235 Уголовно-процессуального кодекса Российской Федерации // СПС КонсультантПлюс.

9. Определение Конституционного Суда Российской Федерации от 21 февраля 2008 года № 138-О-О об отказе в принятии к рассмотрению жалобы гражданина Назаренко Максима Борисовича на нарушение его конституционных прав отдельными положениями статей 17, 56, 74, 79, 240, 246, 271, 274 и 285 Уголовно-процессуального кодекса Российской Федерации // СПС КонсультантПлюс.

10. Постановление Пленума Верховного Суда Российской Федерации от 5 марта 2004 года № 1 «О применении судами норм Уголовно-процессуального кодекса Российской Федерации» (ред. от 9 февраля 2012 года) // СПС КонсультантПлюс. 
DOI: $10.7256 / 1811-9018.2015 .7 .15745$

При цитировании этой статьи сноска на dоі обязательна

\section{Право и политика 7 (187) 2015}

11. Воскобитова Л. А. Объективность как свойство процессуальных решений // Доказывание и принятие решений в современном уголовном судопроизводстве / Материалы международной научно-практической конференции, посвященной памяти доктора юридических наук, профессора Полины Абрамовны Лупинской. М.: МГЮА имени О.Е. Кутафина, 2011. С. $37-48$.

12. Постановление Конституционного Суда Российской Федерации от 8 декабря 2003 года № 18-П «По делу о проверке конституционности положений статей $125,219,227,229,236,237,239,246,254,271,378,405$ и 408 , а также глав 35 и 39 УПК РФ в связи с запросами судов общей юрисдикции и жалобами граждан» // С3 РФ. 2003. № 51. Ст. 5026.

13. Определение Конституционного Суда Российской Федерации от 17 декабря 2009 года № 1636-О-О об отказе в принятии к рассмотрению жалобы гражданина Яшина Владимира Борисовича на нарушение его конституционных прав частью первой статьи 125 и частями первой и второй статьи 171 Уголовно-процессуального кодекса Российской Федерации // СПС КонсультантПлюс.

14. Определение Конституционного Суда Российской Федерации от 21 декабря 2006 года № 589-О об отказе в принятии к рассмотрению жалобы гражданина Чирьева Константина Викторовича на нарушение его конституционных прав частью второй статьи 171 Уголовно-процессуального кодекса Российской Федерации // СПС КонсультантПлюс.

15. Определение Судебной коллегии по уголовным делам Верховного Суда Российской Федерации от 12 января 2010 года № 44-О09-93СП // КонсультантПлюс.

16. Насонов С. А., Ярош С. М. Вердикт присяжных заседателей. М.: Р.Валент, 2003. 160 с.

17. Постановление Пленума Верховного Суда Российской Федерации от 15 июня 2006 года № 14 «О судебной практике по делам о преступлениях, связанных с наркотическими средствами, психотропными, сильнодействующими и ядовитыми веществами» // БВС РФ. 2006. № 8.

18. Постановление Европейского суда по правам человека от 8 февраля 1996 года по делу Джон Мюррей против Соединенного Королевства (John Murray v. the United Kingdom) // Reports of Judgments and Decisions 1996-I.

19. Постановление Европейского суда по правам человека от 29 июня 2007 года по делу О’Халлоран и Фрэнсис против Соединенного Королевства (О. Halloran and Francis v. United Kingdom). Жалобы № 15809/02 и 25624/02 // Бюллетень Европейского Суда по правам человека. 2008. № 1.

20. Определение Судебной коллегии по уголовным делам Архангельского областного суда от 3 декабря 2010 года по делу № $22-3894$ // http://www.arhcourt.ru.

21. Определение Судебной коллегии по уголовным делам Архангельского областного суда от 9 июля 2010 года по делу № $22-2261 / 2010 / /$ http://www.arhcourt.ru.

22. Федеральный закон от 24 июля 2002 года № 102-Ф3 «О третейских судах в Российской Федерации» (ред. от 21 ноября 2011 года) // СПС КонсультантПлюс.

23. Постановление Конституционного Суда Российской Федерации от 29 июня 2004 года № 13 -П по делу о проверке конституционности отдельных положений статей 7, 15, 107, 234 и 450 Уголовно-процессуального кодекса Российской Федерации в связи с запросом группы депутатов Государственной Думы // С3 РФ. 2004. № 27. Ст. 2804.

24. Кругляков А. Оглашение показания, данного на предварительном следствии // Право. Еженедельная юридическая газета. СПб., 1911. № 25. С. 1390.

25. Определение Судебной коллегии Верховного Суда Российской Федерации от 13 июля 2010 года № 11-О10-74 // СПС КонсультантПлюс.

26. Определение Конституционного Суда Российской Федерации от 6 февраля 2004 года № 44-О по жалобе гражданина Демьяненко Владимира Николаевича на нарушение его конституционных прав положениями статей 56, 246, 278 и 355 Уголовно-процессуального кодекса Российской Федерации // СЗ РФ. 2004. № 14. Ст. 1341.

27. Определение Судебной коллегии Кассационной палаты Верховного Суда Российской Федерации от 14 июля 1999 года // БВС РФ. 2000. № 5. С. 3.

28. Определение Судебной коллегии по уголовным делам Верховного Суда Российской Федерации от 8 октября 2013 года № 2-АПУ13-13сп // СПС КонсультантПлюс.

29. Определение Судебной коллегии по уголовным делам Верховного Суда Российской Федерации от 23 сентября 2013 года № 5-АПУ13-49СП // СПС КонсультантПлюс.

30. Определение Судебной коллегии по уголовным делам Верховного Суда Российской Федерации от 11 июня 2013 года № 11-АПУ13-10 // СПС КонсультантПлюс.

31. Определение Судебной коллегии по уголовным делам Верховного Суда Российской Федерации от 19 марта 2013 года № 49-О13-12 // СПС КонсультантПлюс.

32. Определение Судебной коллегии по уголовным делам Верховного Суда Российской Федерации от 6 июня 2012 года № 19-О12-13СП // СПС КонсультантПлюс.

33. Определение Судебной коллегии по уголовным делам Верховного Суда Российской Федерации от 2 августа 2011 года № 58-Д11-13 // СПС КонсультантПлюс.

34. Определение Судебной коллегии по уголовным делам Верховного Суда Российской Федерации от 22 июня 2011 года № 42-О11-3СП // СПС КонсультантПлюс.

35. Определение Судебной коллегии по уголовным делам Верховного Суда Российской Федерации от 9 декабря 2010 года № 19-О10-70сп // СПС КонсультантПлюс.

36. Справка Кемеровского областного суда от 22 августа 2013 года № 01-07/26-495 «О причинах отмены и изменения приговоров и других судебных решений по уголовным делам, постановленных районными (городскими) судами Кемеровской области в 1 полугодии 2013 года» // СПС КонсультантПлюс. 
37. Определение Судебной коллегии по уголовным делам Верховного Суда Российской Федерации от 25 октября 2012 года № 66-О12-82 // СПС КонсультантПлюс.

38. Федеральный закон от 31 мая 2001 года № 73-Ф3 «О государственной судебно-экспертной деятельности в Российской Федерации» (ред. от 25.11.2013) // СПС КонсультантПлюс.

39. Определение Судебной коллегии по уголовным делам Верховного Суда Российской Федерации от 18 октября 2012 года № 58-О12-50 // СПС КонсультантПлюс.

40. Определение Судебной коллегии по уголовным делам Верховного Суда Российской Федерации от 12 июля 2012 года № 72-О12-26 // СПС КонсультантПлюс.

41. Определение Судебной коллегии по гражданским делам Верховного Суда Российской Федерации от 1 марта 2004 года № 8-Г04-8 // СПС КонсультантПлюс.

42. Определение Судебной коллегии по уголовным делам Верховного Суда Российской Федерации от 16 августа 2012 года № 50-О12-23 // СПС КонсультантПлюс.

43. Определение Судебной коллегии по гражданским делам Орловского областного суда от 19 июня 2012 года по делу № 33-1019 // СПС КонсультантПлюс.

44. Определение Судебной коллегии по гражданским делам Хабаровского краевого суда от 6 июля 2012 года по делу № 33-4194 // СПС КонсультантПлюс.

45. Определение Судебной коллегии по гражданским делам Верховного Суда Республики Тыва от 5 июня 2012 года по делу № 275/2012 // СПС КонсультантПлюс.

46. Определение Судебной коллегии по гражданским делам Липецкого областного суда от 2 мая 2012 года по делу № 33959/2012 // СПС КонсультантПлюс.

47. Определение Судебной коллегии по гражданским делам Орловского областного суда от 19 сентября 2012 года по делу № 33-1747 // СПС КонсультантПлюс.

48. Определение Судебной коллегии по гражданским делам Верховного суда Республики Башкортостан от 21 февраля 2012 года по делу № 33-2027/2012 // СПС КонсультантПлюс.

49. Постановление Европейского Суда по правам человека от 4 октября 2007 года по делу Гойгова (Goygova) против Российской Федерации (жалоба № 74240/01) // Российская хроника Европейского Суда. 2009. № 4.

50. Постановление Европейского Суда по правам человека от 24 февраля 2005 года по делу Хашиев (Khashiyev) и Акаева (Akayeva) против Российской Федерации (жалобы № 57942/00 и 57945/00) // Бюллетень Европейского Суда по правам человека. 2005. № 12.

51. Гражданский процессуальный кодекс Российской Федерации от 14 ноября 2002 года № 138-Ф3 (ред. от 28.12.2013) // СПС КонсультантПлюс.

52. Арбитражный процессуальный кодекс Российской Федерации от 24 июля 2002 года № 95-Ф3 (ред. от 02.11.2013) // СПС КонсультантПлюс.

53. Определение Конституционного Суда Российской Федерации от 24 ноября 2005 года № 504-О об отказе в принятии к рассмотрению жалобы гражданина Хисамиева Айрата Ирековича на нарушение его конституционных прав статьей 90 Уголовно-процессуального кодекса Российской Федерации // СПС КонсультантПлюс.

54. Определение Конституционного Суда Российской Федерации от 16 декабря 2008 года № 1076-О-П по жалобам граждан Арбузовой Елены Николаевны, Баланчуковой Александры Васильевны и других на нарушение их конституционных прав частями третьей и пятой статьи 165 Уголовно-процессуального кодекса Российской Федерации // Вестник Конституционного Суда РФ. 2009. № 3.

55. Воскобитова Л.А. Познавательная деятельность суда в уголовном судопроизводстве // LEX RUSSICA (РУССКИЙ ЗАКОН). 2005. № 1. С. 104-107.

56. Кодекс судейской этики. Утвержден VIII Всероссийским съездом судей 19 декабря 2012 года // Бюллетень актов по судебной системе. 2013. № 2.

57. Кодекс этики прокурорского работника. Утвержден приказом Генерального прокурора Российской Федерации от 17 марта 2010 года № 114 // Законность. 2010. № 6.

58. Кодекс этики и служебного поведения федеральных государственных служащих Следственного комитета Российской Федерации. Утвержден Председателем Следственного комитета Российской Федерации 11 апреля 2011 года // СПС КонсультантПлюс.

59. Кодекс профессиональной этики сотрудника органа внутренних дел Российской Федерации. Утвержден Приказом Министра внутренних дел Российской Федерации от 24 декабря 2008 года № 1138 // СПС КонсультантПлюс.

60. Кодекс поведения должностных лиц по поддержанию правопорядка. Принят 17 декабря 1979 года Резолюцией 34/169 на 106-ом пленарном заседании Генеральной Ассамблеи ООН // Международная защита прав и свобод человека. Сборник документов. М.: Юрид. лит., 1990.

61. Международный кодекс поведения государственных должностных лиц. Принят 12 декабря 1996 года Резолюцией 51/59 на 82-ом пленарном заседании 51-ой сессии Генеральной Ассамблеи ООН // СПС КонсультантПлюс.

62. Модельный кодекс поведения для государственных служащих. Приложение к Рекомендации Комитета министров Совета Европы от 11 мая 2000 года № R(2000) 10 о кодексах поведения для государственных служащих // СПС КонсультантПлюс.

63. Владимиров Л. Е. Учение об уголовных доказательствах. Тула: Афтограф, 2000.

64. Вороновский Н. Д. Уголовная техника. Начальный курс : Практическое руководство для работников органов расследования М. : Изд-во НКВД РСФСР, 1931. 
DOI: $10.7256 / 1811-9018.2015 .7 .15745$

При цитировании этой статьи сноска на доі обязательна

\section{Право и политика 7 (187) 2015}

65. Определение Судебной коллегии по уголовным делам Верховного Суда Российской Федерации от 7 ноября 2007 года № 34-О07-32 // СПС КонсультантПлюс.

66. Определение Судебной коллегии по уголовным делам Верховного Суда Российской Федерации от 13 июля 2005 года № 55-о05-7 // СПС КонсультантПлюс.

67. Определение Судебной коллегии по уголовным делам Верховного Суда Российской Федерации от 17 сентября 2008 года № 92-О08-17 // СПС КонсультантПлюс.

68. Определение Судебной коллегии по уголовным делам Верховного Суда Российской Федерации от 30 октября 2008 года по делу № 3-008-27 // СПС КонсультантПлюс.

\section{References (transliterated):}

1. Nasonov S. A. Naputstvennoe slovo predsedatel'stvuyushchego v sude prisyazhnykh. M.: R.Valent, 2006.304 s.

2. Voskobitova L. A. Ob' 'ektivnost' kak svoistvo protsessual'nykh reshenii // Dokazyvanie i prinyatie reshenii v sovremennom ugolovnom sudoproizvodstve / Materialy mezhdunarodnoi nauchno-prakticheskoi konferentsii, posvyashchennoi pamyati doktora yuridicheskikh nauk, professora Poliny Abramovny Lupinskoi. M.: MGYuA imeni O.E. Kutafina, 2011. S. 37-48.

3. Nasonov S. A., Yarosh S. M. Verdikt prisyazhnykh zasedatelei. M.: R.Valent, 2003. 160 s.

4. Kruglyakov A. Oglashenie pokazaniya, dannogo na predvaritel'nom sledstvii // Pravo. Ezhenedel'naya yuridicheskaya gazeta. SPb., 1911. № 25. S. 1390.

5. Voskobitova L.A. Poznavatel'naya deyatel'nost' suda v ugolovnom sudoproizvodstve // LEX RUSSICA (RUSSKII ZAKON). 2005. № 1. S. 104-107.

6. Vladimirov L. E. Uchenie ob ugolovnykh dokazatel'stvakh. Tula: Aftograf, 2000.

7. Voronovskii N. D. Ugolovnaya tekhnika. Nachal'nyi kurs : Prakticheskoe rukovodstvo dlya rabotnikov organov rassledovaniya M. : Izd-vo NKVD RSFSR, 1931. 